\title{
Temperature effect on physical and chemical properties of secondary organic aerosol from $m$-xylene photooxidation
}

\author{
L. Qi, S. Nakao, P. Tang, and D. R. Cocker III \\ Department of Chemical and Environmental Engineering, Bourns College of Engineering, University of California, Riverside, \\ CA 92521, USA and College of Engineering, Center for Environmental Research and Technology (CE-CERT), 1084 \\ Columbia Avenue, Riverside, CA 92507, USA
}

Received: 11 December 2009 - Published in Atmos. Chem. Phys. Discuss.: 15 January 2010

Revised: 3 April 2010 - Accepted: 12 April 2010 - Published: 26 April 2010

\begin{abstract}
The chemical and physical differences of secondary organic aerosol (SOA) formed at select isothermal temperatures $(278 \mathrm{~K}, 300 \mathrm{~K}$, and $313 \mathrm{~K})$ are explored with respect to density, particle volatility, particle hygroscopicity, and elemental chemical composition. A transition point in SOA density, volatility, hygroscopicity and elemental composition is observed near 290-292 K as SOA within an environmental chamber is heated from $278 \mathrm{~K}$ to $313 \mathrm{~K}$, indicating the presence of a thermally labile compound. No such transition points are observed for SOA produced at $313 \mathrm{~K}$ or $300 \mathrm{~K}$ and subsequently cooled to $278 \mathrm{~K}$. The SOA formed at the lowest temperatures $(278 \mathrm{~K})$ is more than double the SOA formed at $313 \mathrm{~K}$. SOA formed at $278 \mathrm{~K}$ is less hydrophilic and oxygenated while more volatile and dense than SOA formed at $300 \mathrm{~K}$ or $313 \mathrm{~K}$. The properties of SOA formed at $300 \mathrm{~K}$ and $313 \mathrm{~K}$ when reduced to $278 \mathrm{~K}$ did not match the properties of SOA initially formed at $278 \mathrm{~K}$. This study demonstrates that it is insufficient to utilize the enthalpy of vaporization when predicting SOA temperature dependence.
\end{abstract}

\section{Introduction}

SOA is organic aerosol formed from gas-phase oxidative processing of volatile organic compounds (VOCs) in the atmosphere (e.g., Kroll and Seinfeld, 2008). SOA comprises up to $80 \%$ of all ambient organic aerosol present (Turpin, et al., 1995; Zhang et al., 2007) and contributes to climatic impacts, regional visibility reduction and potential health haz-

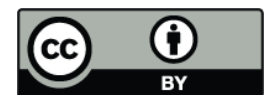

Correspondence to: D. R. Cocker III (dcocker@engr.ucr.edu) ards (IPCC, 2007; Eldering and Cass, 1996; Davidson et al., 2005; Pope and Dockery, 2006).

Due to the complexity of atmospheric organic compounds, indirect methods have been employed to estimate SOA formation. Pankow (1994a, b) and Odum et al. (1996) developed a thermodynamic method combined with an empirical model which has been widely used to analyze SOA formation within environmental chambers. Organic aerosol yield $(Y)$ is utilized to describe the SOA formation potential of a parent compound and is expressed as

$Y=\sum_{i} Y_{i}=M_{o} \sum_{i} \frac{\alpha_{i} K_{o m, i}}{1+K_{o m, i} M_{o}}$

where $M_{o}$ is the organic aerosol mass concentration $\left(\mu \mathrm{g} \mathrm{m}^{-3}\right), \alpha_{i}$ is the mass based stoichiometric coefficient and $\mathrm{K}_{o m, i}$ is the gas-particle partitioning coefficient of compound $i$, respectively. $\mathrm{K}_{o m, i}$ is then calculated as

$K_{o m, i}=\frac{R T}{\mathrm{MW}_{o m, i} \gamma_{i} p_{L, i}^{o}}$

where $R$ is the ideal gas constant, $\mathrm{MW}_{o m, i}$ is the molecular weight of species $i, T$ is temperature, and $\gamma_{i}$ and $p_{L, i}^{o}$ are the activity coefficient and saturation liquid vapor pressure, respectively, of compound $i$. These final two parameters are both functions of $T$. However, it is difficult to obtain the thermodynamic parameters for each individual specie to assess the extent to which the above equations can handle $T$ dependence in an SOA forming system. Given the wide ranges of tropospheric temperatures, it is necessary to accurately predict temperature dependences when describing SOA formation. This work demonstrates the presence of thermally labile species that are not accounted for in current thermodynamic equilibrium models.

Published by Copernicus Publications on behalf of the European Geosciences Union. 
There has been considerable amount of work on aerosol yields from the ozonolysis of $\alpha$-pinene near room temperature (e.g., Hoffmann et al., 1997; Griffin et al., 1999; Cocker et al., 2001a; Berndt et al., 2003; Pathak et al.,2007a; Shiling et al., 2008), while studies covering more extended temperature ranges are very limited (Stainer et al., 2007; Pathak et al., 2007b) and work on aromatic hydrocarbons are even more rare (Takekawa et al., 2003). These earlier studies report SOA volume dependence per $\mathrm{K}\left({ }^{\circ} \mathrm{C}\right)$. Most recently, Warren et al. (2009a) explored the reversibility of SOA formation with temperature for the cyclohexene and $\alpha$-pinene ozonolysis systems and showed strong evidence that either gas-particle or particle-phase reaction are temperature dependent. This paper presents for the first-time a comprehensive investigation of temperature dependence for both physical and chemical properties of SOA produced in an environmental chamber.

\section{Experimental section}

\subsection{Facility overview}

Experiments were conducted in the UC Riverside/CE-CERT indoor environmental chamber, which is described in detail elsewhere (Carter et al., 2003). Dual $90 \mathrm{~m}^{3}$ Teflon reactors are suspended by a rigid steel framework in a temperaturecontrolled enclosure which is continuously flushed with purified air. The enclosure is temperature controlled within $\pm 0.5 \mathrm{~K}$ of the set point, with operational temperatures ranging from $273 \mathrm{~K}$ to $323 \mathrm{~K}$. The rigid framework slowly collapses the reactors during the experiments to minimize leaks and diffusion of contaminants into the reactors by maintaining a positive $0.03^{\prime \prime} \mathrm{H}_{2} \mathrm{O}$ differential pressure between the reactors and enclosure. $115 \mathrm{~W}$ Sylvania 350 black lights are used as light sources for all the experiments. Different numbers of light bulbs are used to match the $\mathrm{NO}_{2}$ photolysis rate at different temperatures. A known volume of high purity liquid hydrocarbon precursor ( $m$-xylene: SigmaAldrich, $\geq 99.5 \%$ ) is injected through a heated glass injection manifold system and flushed into the chamber with pure $\mathrm{N}_{2}$. $\mathrm{NO}_{2}$ is introduced by flushing pure $\mathrm{N}_{2}$ through a calibrated glass bulb filled to a predetermined partial pressure of pure $\mathrm{NO}_{2}$. For all experiments, after the non-wall loss corrected SOA volume started decay, the enclosure temperature was raised/lowered to another set point.

\subsection{Light intensity}

The intensity of fluorescent blacklight lamps will decrease with decreasing room temperature. Furthermore, Warren et al. (2009b) recently reported that SOA formation for aromatic systems is a strong function of $\mathrm{NO}_{2}$ photolysis rate (denoted as $\mathrm{K}_{1}$ ). Therefore, it was essential that the $\mathrm{NO}_{2}$ photolysis rate be maintained between experiments conducted at different temperatures. A series of $\mathrm{K}_{1}$ measurements (described in Carter et al., 2003) were performed varying temperature and number of lamps to ensure that a consistent $\mathrm{K}_{1}$ was achieved. In this study, a photolysis rate of $0.29 \mathrm{~min}^{-1}$ was achieved for all experiments regardless of the system temperature.

\subsection{Particle and gas measurements}

Particle size distributions between 28 and $735 \mathrm{~nm}$ are monitored with scanning mobility particle sizers (SMPS) located inside a temperature controlled enclosure. Particle sizing was verified with a suite of polystyrene latex spheres (PSL) (Duke Scientific Corp., Palo Alto, CA).

Real-time particle density is measured using an Aerosol Particle Mass Analyzer (APM) (Kanomax model 3600) and SMPS in series. A custom Labview program determines mode diameter peak from a parallel SMPS and then actively configures the APM-SMPS to optimize instrument response. Density is acquired approximately every $75 \mathrm{~s}$. Details of the instruments and theory are described elsewhere (Malloy et al., 2009; Ehara et al., 1996).

The hygroscopicity of chamber derived SOA is continuously monitored with a custom-built Hygroscopic Tandem Differential Mobility Analyzer (HTDMA). The instrument follows the original design of Radar and McMurry with the configuration similar to that illustrated in Cocker et al. (2001b). The particle diameter transmitted through the first SMPS was selected to match the peak size distribution measured by a parallel SMPS. Hygroscopic growth factor is reported as the ratio of the modal diameter of humidified aerosol $(85.0 \% \sim 95.0 \% \pm 1.0 \%), D_{p}$, humidified, to that of classified aerosol, $D_{p \text {,dry }}$, i.e., $G_{f}=D_{p \text {, humidified }} / D_{p \text {,dry }}$. Both size distributions are fitted to log-normal distributions to get

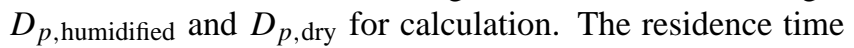
of the humidification system is approximately $1 \mathrm{~min}$. The HTDMA measurement is validated with lab-generated dry ammonium sulfate salt. The $G_{f}$ is found to agree within $1.0 \%$ of theoretically calculated result using Köhler model at similar RH level (Brechtel and Kreidenweis, 2000). Parallel to the humidification system is a Dekati thermal denuder (TD) (model WAN 5912-4, Dekati Ltd., Finland) system with a $17 \mathrm{~s}$ heating zone residence time (0.25 LPM flow rate) that can be alternatively operated to evaluate SOA volatility (VTDMA mode). The heating zone of the TD is set to $100^{\circ} \mathrm{C}$. Volume remaining fraction (VRF) is then calculated as $\left(D_{p, \text { after TD }} / D_{p \text {, before TD }}\right)^{3}$.

The evolution of particle elemental composition of aerosol particles is tracked using an Aerodyne High Resolution Time-of-Flight Aerosol Mass Spectrometry (HR-ToF-AMS) operating in the high resolution mode (deCarlo et al., 2006; Jimenez et al., 2003). The HR-ToF-AMS has been described in detail previously (deCarlo et al., 2006) and improves on mass resolution by using a custom high-resolution ToFMS (Tofwerk, Switzerland). More recently, a new elemental 
analysis (EA) technique was developed using HR-ToF-AMS sampling data (Aiken et al., 2007, 2008). The method is based on the property of electron ionization (EI) for molecules containing small atoms such as $\mathrm{C}, \mathrm{H}, \mathrm{N}, \mathrm{O}$ and $\mathrm{S}$ that the sum of the ion signal intensities from all fragments is approximately proportional to the mass concentration of the original organic species. Thus, if the elemental composition of each fragment ion signal in a mass spectrum can be identified (as with HR mass spectra), the average composition of the ions can be calculated. For a complex spectrum from an unknown molecule or mixture, the best estimate of the composition can then be found by summing up the ion contributions across the entire mass spectrum, which is then represented as estimated ratios of oxygen-tocarbon $(\mathrm{O} / \mathrm{C})$, hydrogen-to-carbon $(\mathrm{H} / \mathrm{C})$, and nitrogen-tocarbon (N/C). Estimated atomic ratios are used to calculated Organic Matter (OM)/Organic Carbon (OC). In this study, the $\mathrm{C}: \mathrm{O}: \mathrm{H}$ ratio of the total aerosol was determined using the high resolution capabilities of the HR-ToF-AMS following the Peak Integration by Key Analysis (PIKA) and Analytical Procedure for Elemental Separation (APES) templates (deCarlo et al., 2006; Aiken et al., 2008). The sampling lines for APM, TDMA and AMS measurements were wrapped with insulation foam materials to prevent condensation/evaporation of semi-volatile components during sampling.

Decay of the parent hydrocarbon species is monitored with a gas chromatograph equipped with a flame ionization detector (GC-FID, Agilent 6890, Palo Alto, CA). A Thermal Environmental Instruments Model $42 \mathrm{C}$ measured $\mathrm{NO}, \mathrm{NO}_{\mathrm{y}}$ and $\left(\mathrm{NO}_{\mathrm{y}}-\mathrm{NO}\right)$ concentration. $\mathrm{O}_{3}$ is monitored with a Dasibi Environmental Corp. Model 1003- $\mathrm{AH} \mathrm{O}_{3}$ analyzer.

\section{Results and discussions}

\subsection{SOA production}

A series of $6 m$-xylene/ $\mathrm{NO}_{\mathrm{x}}$ photooxidation isothermal experiments (listed in Table 1) were conducted under dry $(\mathrm{RH}<0.1 \%)$, non-seed conditions using the UCR/CE-CERT environmental chamber at three temperature set points $(278 \mathrm{~K}, 300 \mathrm{~K}, 313 \mathrm{~K})$. Temperature was then changed after 6-7 $\mathrm{h}$ irradiation to evaluate the response of the SOA to temperature change. Initial $m$-xylene concentrations ranged from $107 \mathrm{ppb}$ to $125 \mathrm{ppb}$, while $\mathrm{NO}_{2}$ concentrations ranged from $14.8 \mathrm{ppb}$ to $17.4 \mathrm{ppb}$. Figure $1 \mathrm{a}-\mathrm{c}$ displays the raw aerosol volume for all temperature conditions. The maximum raw volume are $23.5 \mu \mathrm{m}^{3} \mathrm{~cm}^{-3}, 15.3 \mu \mathrm{m}^{3} \mathrm{~cm}^{-3}$ and $9.9 \mathrm{~mm}^{3} \mathrm{~cm}^{-3}$ for $278 \mathrm{~K}, 300 \mathrm{~K}$ and $313 \mathrm{~K}$, respectively. The enclosure was then heated or cooled to evaluate whether the SOA would obey gas-particle partitioning theory. For the experiment commencing at $278 \mathrm{~K}$, the volume concentration dropped by $3.7 \mu \mathrm{m}^{3} \mathrm{~cm}^{-3}$ when heated to $313 \mathrm{~K}$. The decrease in the volume concentration is calculated as the differ-
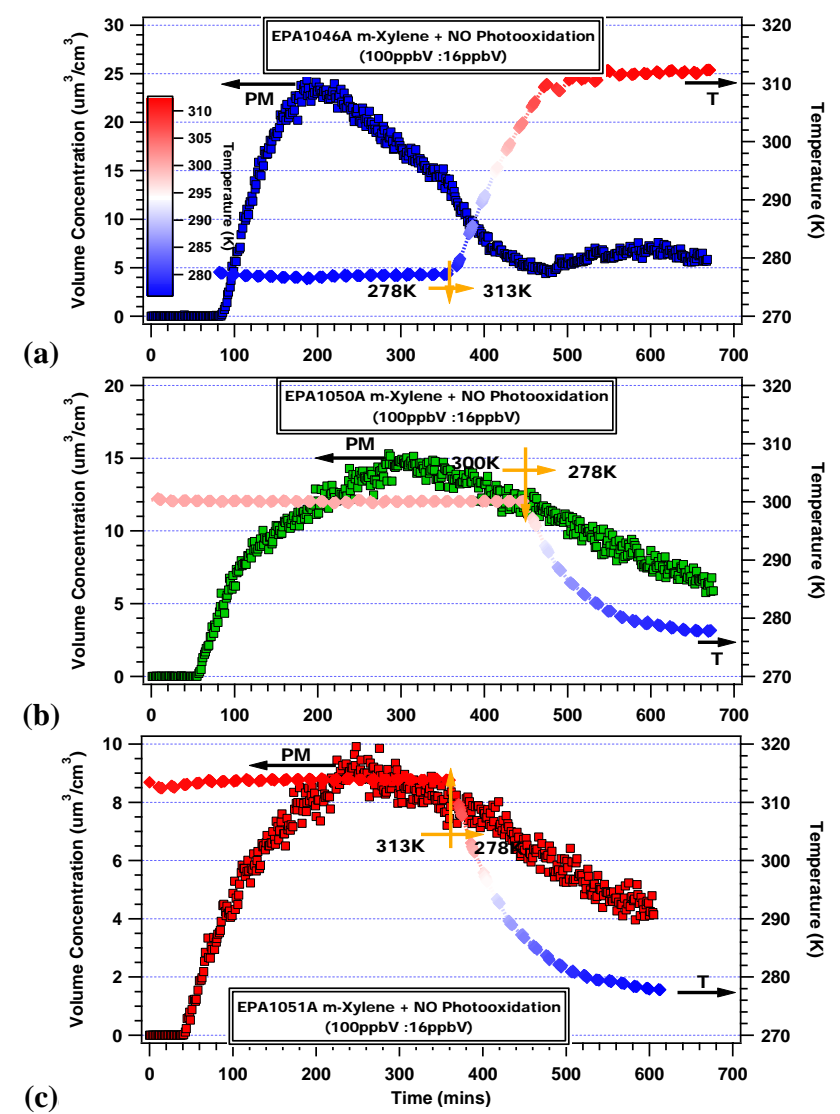

Fig. 1. Aerosol formation results for three selected temperature experiments; all three dry non-seeded photooxidation with initial target concentration ( $m$-xylene $\approx 100 \mathrm{ppb}, \mathrm{NO}_{2} \approx 16 \mathrm{ppb}$ ). Blue squares represent the experiment starting at $278 \mathrm{~K}$ for $6 \mathrm{~h}$ irradiation and then heated to $313 \mathrm{~K}$; green squares represent the experiment starting at $300 \mathrm{~K}$ for $7.5 \mathrm{~h}$ irradiation and then cooled to $278 \mathrm{~K}$; red squares represent the experiment starting at $313 \mathrm{~K}$ for $6 \mathrm{~h}$ irradiation and then cooled to $278 \mathrm{~K}$.

ence between the projected non-wall loss corrected volume assuming the temperature was unchanged $(278 \mathrm{~K})$ and the actual measured volume concentration when heated to $313 \mathrm{~K}$. For the room temperature $(300 \mathrm{~K})$ experiment, the volume concentration increased by $1.6 \mu \mathrm{m}^{3} \mathrm{~cm}^{-3}$ when cooled to $278 \mathrm{~K}$. For the $313 \mathrm{~K}$ run, it gained $1.7 \mu \mathrm{m}^{3} \mathrm{~cm}^{-3}$ when the temperature was lowered to $278 \mathrm{~K}$. These results show that this system is unable to partition between temperature set points, indicating the thermodynamic gas-particle partitioning theory alone cannot explain the difference of SOA formation at the temperature set points for this specific system.

\subsection{SOA density}

The evolution of aerosol effective density and the temperature profile of the system over the course of the experiment are presented in Fig. 2. When the experiment starts at $278 \mathrm{~K}$, the effective density stabilizes at $1.50-1.60 \mathrm{~g} \mathrm{~cm}^{-3}$ with the 
Table 1. Experimental conditions and results summary for the $m$-xylene photooxidation reactions.

\begin{tabular}{llllllll}
\hline & & & & \multicolumn{4}{c}{ Temp Change } \\
Exp \# & $T_{0}$ & $\begin{array}{l}\mathrm{NO}_{2, i} \\
{[\mathrm{~K}]}\end{array}$ & $\begin{array}{l}m \text {-xylene, }{ }_{i} \\
{\left[\mu \mathrm{ppb}^{-3}\right]}\end{array}$ & $\begin{array}{l}\left.\Delta m \text {-xylene }^{-3}\right] \\
{\left[\mu \mathrm{g} \mathrm{m}^{-3}\right]^{\mathrm{a}}}\end{array}$ & $\begin{array}{l}\Delta M_{o} \\
{\left[\mu \mathrm{g} \mathrm{m}^{-3}\right]^{\mathrm{b}}}\end{array}$ & $\begin{array}{l}T_{2} \\
{[\mathrm{~K}]}\end{array}$ & $\begin{array}{l}\Delta M_{o} \\
{\left[\mu \mathrm{g} \mathrm{m}^{-3}\right]^{\mathrm{c}}}\end{array}$ \\
\hline 1046A & 278 & 15.7 & 544 & 223 & 13.3 & 313 & $\downarrow 3.7$ \\
$1047 \mathrm{~A}$ & 313 & 15.0 & 475 & 322 & - & 278 & - \\
$1049 \mathrm{~A}$ & 300 & 14.8 & 465 & 310 & 11.0 & 313 & $\downarrow 2.9$ \\
$1050 \mathrm{~A}$ & 300 & 17.4 & 491 & 332 & 11.6 & 278 & $\uparrow 1.6$ \\
$1051 \mathrm{~A}$ & 313 & 16.4 & 483 & 330 & 7.4 & 278 & $\uparrow 1.7$ \\
$1055 \mathrm{~A}$ & 278 & 15.6 & 604 & 279 & 15.3 & 313 & $\downarrow 3.4$ \\
\hline
\end{tabular}

a this is the hydrocarbon consumed by the time when system temperature starts to change. ${ }^{b}$ non-wall-loss corrected PM volume concentration before system temperature changes (not the maximum volume concentration that the system achieved). ${ }^{\mathrm{c}}$ particle mass condensed/evaporated when lowering/increasing the system temperature compared to the projected particle mass if the system remains at the initial temperature.

(a)

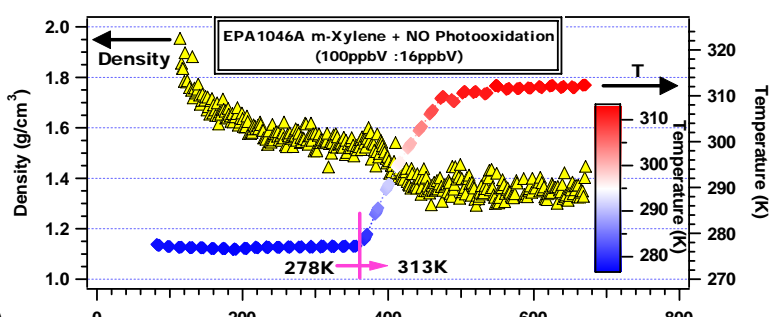

(b)
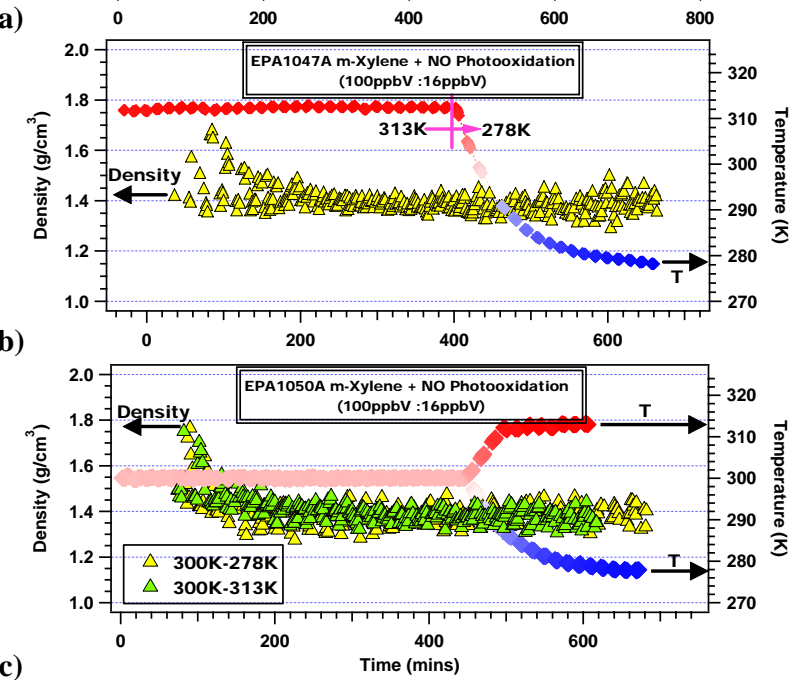

Fig. 2. The time evolution of particle density for four selected temperature experiments: initial concentrations $m$-xylene $\approx 100 \mathrm{ppb}$, $\mathrm{NO}_{2} \approx 16 \mathrm{ppb}$ for (a-c); (a) $278 \mathrm{~K} \rightarrow 313 \mathrm{~K}$, (b) $313 \mathrm{~K} \rightarrow 278 \mathrm{~K}$, (c) $300 \mathrm{~K} \rightarrow 278 \mathrm{~K} ; 300 \mathrm{~K} \rightarrow 313 \mathrm{~K}$.

initial nucleation species density as high as $1.90 \mathrm{~g} \mathrm{~cm}^{-3}$. When the system is heated from $278 \mathrm{~K}$ to $313 \mathrm{~K}$, a transition point in SOA density is observed near 290-292 K, with the final density approaching $\sim 1.35 \mathrm{~g} \mathrm{~cm}^{-3}$ as the system approaches $313 \mathrm{~K}$ (Fig. 2a). The sudden drop in SOA density near 290-292 K suggests a dramatic change in particle-phase product distribution. However, when the experiment starts at $313 \mathrm{~K}$, effective density remains constant at $\sim 1.4 \mathrm{~g} \mathrm{~cm}^{-3}$ (with slightly higher density at the onset of aerosol formation) even when the system was cooled to $278 \mathrm{~K}$ (Fig. 2b). The density of SOA formed at $300 \mathrm{~K}\left(1.4 \mathrm{~g} \mathrm{~cm}^{-3}\right)$ is comparable to that formed at $313 \mathrm{~K}$ and does not change when either raising the temperature to $313 \mathrm{~K}$ or lowering the temperature to $278 \mathrm{~K}$ (Fig. 2c). These density trends are consistent with earlier work on $m$-xylene photooxidation by Malloy et al. (2009) conducted at $300 \mathrm{~K}$. The differences in density behavior at the temperature set points may be attributed to the formation of thermally labile aerosol component(s) that are produced at the lower reaction temperatures but break when the temperature increases to 290-292 K.

\subsection{SOA hygroscopicity}

Real-time hygroscopic growth factors for select experiments using HTDMA are shown in Fig. 3. When the experiment starts at $278 \mathrm{~K}$, the hygroscopicity of $m$-xylene photooxidation aerosol shows a continuous increase of $G_{f}(1.02-1.09$ in Fig. 3a) at $81.0 \pm 0.5 \% \mathrm{RH}$, which is similar to previously observed phenomena at room temperature (e.g., Qi et al., 2009; Cocker et al., 2001c). When the system is heated from $278 \mathrm{~K}$ to $313 \mathrm{~K}$, a transition point in SOA $G_{f}$ is observed near 290 $292 \mathrm{~K}$, consistent with the transition point observed in the SOA density. The $G_{f}$ then continues to slowly increase to 1.17 at $313 \mathrm{~K}$. When the reaction starts at $313 \mathrm{~K}$, the $G_{f}$ is observed to increase from 1.05 to 1.15 over $7 \mathrm{~h}$ irradiation at the same TDMA RH level. Similar to the density observations, no $G_{f}$ transition point is observed as the system is cooled to $278 \mathrm{~K}$ from $313 \mathrm{~K}$, nor is the $G_{f}$ impacted by the decreasing temperature. Again, the $G_{f}$ observations are consistent with the formation of thermally labile specie(s) at low chamber temperatures that break around 290-292 K. 
(a)

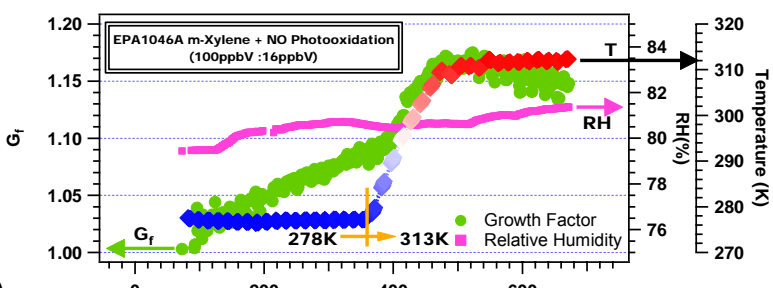

(b)

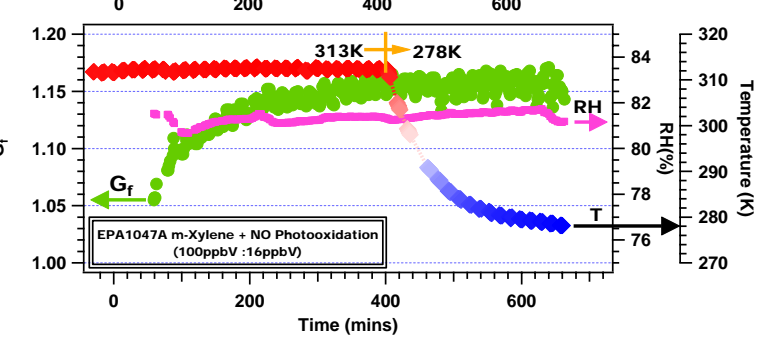

Fig. 3. Growth factor and RH for $m$-xylene photooxidation experiments at two different temperatures.

\subsection{SOA volatility}

Measurement of SOA volatility can provide indirect information about its chemical composition (Philippin et al., 2003; Kalberer et al., 2004). The SOA VRF for $m$-xylene photooxidation experiments conducted at $278 \mathrm{~K}, 300 \mathrm{~K}$, and $313 \mathrm{~K}$ are shown in Fig. 4a-c. The VRF of the SOA after $4 \mathrm{~h}$ UV irradiation is $14 \%, 29 \%$, and $48 \%$ for the $278 \mathrm{~K}, 300 \mathrm{~K}$, and $313 \mathrm{~K}$ systems, respectively. VRFs are observed to increase during the isothermal phase of the reaction for all three systems' $T$ set points. Overall, the volatility of SOA at different temperatures is $278 \mathrm{~K}>300 \mathrm{~K}>313 \mathrm{~K}$, consistent with additional condensation of high vapor pressure semivolatile species at the lower isothermal $T$ set points. When reducing the temperatures of the $300 \mathrm{~K}$ and $313 \mathrm{~K}$ systems to $278 \mathrm{~K}$, there is an immediate decrease in VRF observed for both systems, consistent with condensation of additional semi-volatile species as the system $T$ lowers, which is easily re-evaporated at the $100^{\circ} \mathrm{C}$ TD set point. The VRFs decrease to $33 \%$ and $40 \%$ for $300 \mathrm{~K}$ and $313 \mathrm{~K}$ experiments, respectively, when the system temperatures arrive at $278 \mathrm{~K}$. These VRFs remain higher than the projected VRF ( $\sim 24 \%)$ for the low temperature system. For the $278 \mathrm{~K}$ experiment, the VRF slowly increases when the system starts heating up, and then shows a steeper increase when the system temperature approaches the 290-292 K threshold. The VRF time traces are consistent with the density and $\mathrm{G}_{f}$ observations for the $278 \mathrm{~K}$ experiment when heated past 290-292 K and are consistent with a thermally labile portion of the aerosol formed at the lowest $T$ set point.

\subsection{SOA chemical composition}

As a result of both the extensive fragmentation caused by electron impact ionization and the thermal decomposition

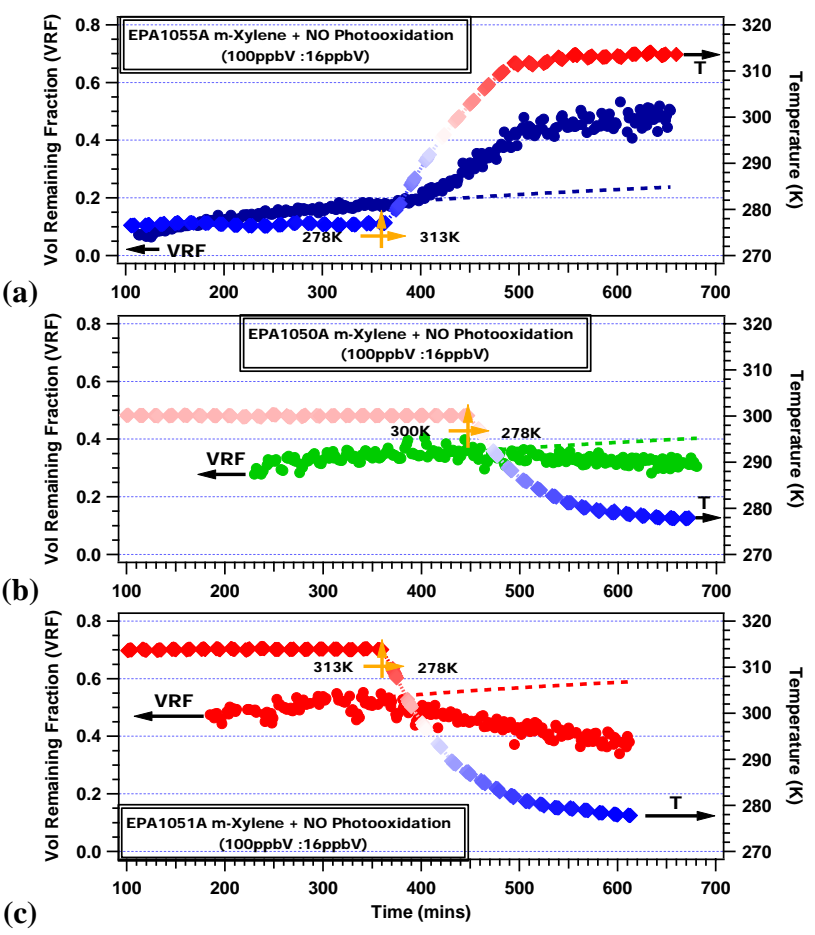

Fig. 4. The volume remaining fraction in typical operating schemes for $m$-xylene photooxidation experiment at three temperatures (a) $278 \mathrm{~K} \rightarrow 313 \mathrm{~K}$; (b) $300 \mathrm{~K} \rightarrow 278 \mathrm{~K}$; (c) $313 \mathrm{~K} \rightarrow 278 \mathrm{~K}$.

of molecules by the vaporizer, most of the signal intensity in the HR-ToF-AMS occurred below mass to charge ratio $(m / z) 100$; parent molecular peaks were weak or unobserved. Therefore, $m / z$ values of fragment ions were interpreted as tracers of the parent species and the change in contribution fraction of signal intensities could be attributed to evolution of aerosol species (e.g., change in signal intensity ratio of $m / z 44 / 43$ ). For instance, $m / z 44$ is commonly associated with fragments of oxo- and dicarboxylic acids $\left(\mathrm{CO}_{2}^{+}\right)$while $m / z \quad 43$ is a fragment normally associated with oxidized organic molecules containing carbonyl groups $\left(\mathrm{C}_{2} \mathrm{H}_{3} \mathrm{O}^{+}\right)$(Alfarra et al., 2006). The average mass spectra of organics normalized to the total organic signal are displayed in Fig. 5. The same fragmentation table was used as that in Aiken et al. (2008). When the reaction starts at $278 \mathrm{~K}$, the relative intensity of $\mathrm{m} / z 44\left(\mathrm{CO}_{2}^{+}\right)$is $6.5 \%$ and then increases to $8.4 \%$ when the system temperature reaches $313 \mathrm{~K}$. However, when the reaction starts at $313 \mathrm{~K}$ and then cooled down to $278 \mathrm{~K}$, the contribution fraction of $\mathrm{CO}_{2}^{+}$ion is considerably higher and only changes from $10.0 \%$ to $9.7 \%$. These results indicate that for this system the SOA produced at cold temperatures are less oxygenated than those produced at higher temperatures and that less oxygenated species are preferentially lost from the aerosol as the system is heated. The change in $m / z, 44$ relative intensity upon heating is attributed to evaporation of lighterend semi-volatile species that may be less functionalized 

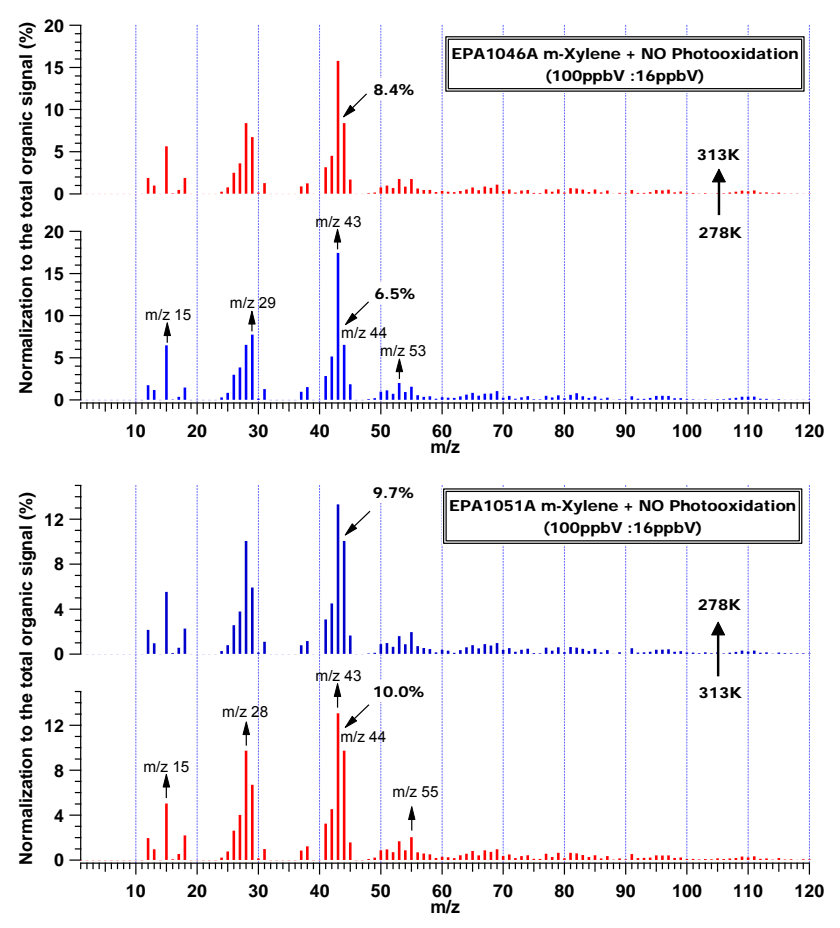

Fig. 5. The normalized average mass spectra of total organics for $m$-xylene photooxidation experiment at two temperatures $(278 \mathrm{~K}$, $313 \mathrm{~K})$.

(oxygenated). The much higher $m / z 44$ intensity for species in the $313 \mathrm{~K}$ isothermal experiment indicates that production of higher oxygen-containing compounds are favored at these higher temperatures. Similar phenomena were also observed in toluene/ $\mathrm{NO}_{\mathrm{x}}$ photooxidation reaction system (Hildebrandt et al., 2009). Furthermore, it is consistent with the other analytical techniques described in previous sections that the semi-volatile species formed at $313 \mathrm{~K}$ differ in composition from those formed at $278 \mathrm{~K}$. Furthermore, the $278 \mathrm{~K}$ aerosol composition cannot be produced by condensation of semivolatile species when cooling the system from $313 \mathrm{~K}$ system to $278 \mathrm{~K}$. In other words, simple thermodynamic partitioning theory alone can not fully explain the data.

Organic elemental analysis (EA) was applied to HRToF-AMS SOA data collected from select experiments. Time series for $\mathrm{O} / \mathrm{C}$ ratio for $m$-xylene photooxidation at cold temperature $(278 \mathrm{~K} \rightarrow 313 \mathrm{~K})$ and hot temperature $(313 \mathrm{~K} \rightarrow 278 \mathrm{~K})$ are presented in Fig. 6. Values are not presented for aerosol mass loadings less than $2.0 \mu \mathrm{g} \mathrm{m}^{-3}$ to reduce scatter at low mass loadings. O/C values of $0.40 \pm 0.02$ were observed for the SOA from $m$-xylene photooxidation at $278 \mathrm{~K}$. Overall, the $\mathrm{O} / \mathrm{C}$ ratio remains stable for $6 \mathrm{~h}$ while the system is maintained at $278 \mathrm{~K}$ and then slowly increases as the system temperature increases. There is an evident increase in $\mathrm{O} / \mathrm{C}$ ratio when the system is heated to about 290-292 K. This observation is consistent with increasing organic functionalization of the suspended aerosol as the sys-

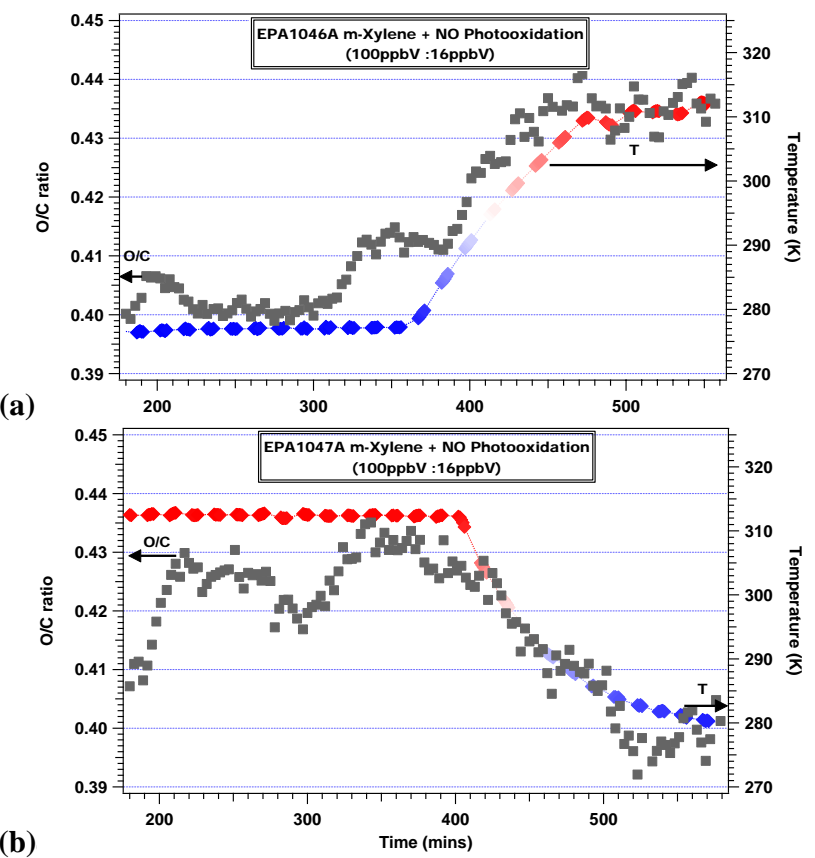

Fig. 6. The time series of $\mathrm{O} / \mathrm{C}$ ratio for $m$-xylene photooxidation experiment at cold (a: $278 \mathrm{~K} \rightarrow 313 \mathrm{~K})$ and hot temperature (b: $313 \mathrm{~K} \rightarrow 278 \mathrm{~K}$ ). The grey square represents real-time O/C ratio.

tem crosses $290-292 \mathrm{~K}$, which is also inferred above from the HTDMA, VTDMA and density measurements. O/C values of $0.43 \pm 0.03$ were observed for the SOA from $m$-xylene photooxidation at $313 \mathrm{~K}$, and it slowly decreases as the system is cooled down, which can be attributed to a fraction of less oxidized compounds condensation.

\section{Conclusions}

Temperature has a clear and dramatic effect on the SOA formation not only in terms of particle volume but also chemical composition for the $m$-xylene photooxidation system. For the first time, strong evidence from perspectives of particle density, hygroscopicity, volatility and bulk elemental analysis is presented that the semi-volatile formation or particlephase reactions are temperature dependent for this specific system. The results show that when the experiment commences at $313 \mathrm{~K}$, and then is cooled down to $278 \mathrm{~K}$, there are no significant changes in particle density, hygroscopicity, volatility, and chemical composition. However, aerosol formed at cold temperatures appears chemically and physically different than those formed at $300 \mathrm{~K}$ and $313 \mathrm{~K}$. These observations indicate that traditional gas-particle partitioning theory alone can not fully explain $m$-xylene photooxidation system temperature dependence. A large transition in particle density, hygroscopicity, volatility and chemical composition was seen as the aerosol was warmed past $290-292 \mathrm{~K}$. 
These observations are consistent with a thermally labile aerosol component.

This study indicates that it is insufficient to utilize enthalpy of vaporization or percent volume change per degree to predict SOA formation for differences in temperature with current models. The reason is apparently due to the fundamentally difference in physical and chemical properties of SOA formed at different temperatures. Further study is needed to identify the source and composition of the thermally labile species to allow for prediction of the SOA temperature dependence for this system. Therefore, the reaction mechanism can be improved accordingly. Other systems must be explored to identify the extent to which the phenomena observed for the $m$-xylene photooxidation experiment is present in other SOA systems.

Acknowledgements. This research described in this paper has been funded by the National Science Foundation, ATM\#0449778, and the W. M. Keck Foundation, which have not endorsed this publication and the views expressed herein may not reflect their views. The authors thank Kurt Bumiller, Charles Bufalino, Bethany Warren, Quentin Malloy for technical support and Dylan Switzer for the help with experiment.

Edited by: R. Holzinger

\section{References}

Aiken, A. C., DeCarlo, P. F., and Jimenez, J. L.: Elemental analysis of organic species with electron ionization high-resolution mass spectrometry, Anal. Chem., 79(21), 8350-8358, 2007.

Aiken, A. C., DeCarlo, P. F., Kroll, J. H., Worsnop, D. R., Huffman, J. A., Docherty, K., Ulbrich, I. M., Mohr, C., Kimmel, J. R., Sueper, D., Zhang, Q., Sun, Y., Trimborn, A., Northway, M., Ziemann, P. J., Canagaratna, M. R., Onasch, T. B., Alfarra, R., Prevot, A. S. H., Dommen, J., Duplissy, J., Metzger, A., Baltensperger, U., and Jimenez, J. L.: O/C and OM/OC Ratios of Primary, Secondary, and Ambient Organic Aerosols with High Resolution Time-of-Flight Aerosol Mass Spectrometry, Environ. Sci. Technol., 42, 4478-4485, 2008.

Alfarra, M. R., Paulsen, D., Gysel, M., Garforth, A. A., Dommen, J., Prvt, A. S. H., Worsnop, D. R., Baltensperger, U., and Coe, H.: A mass spectrometric study of secondary organic aerosols formed from the photooxidation of anthropogenic and biogenic precursors in a reaction chamber, Atmos. Chem. Phys., 6, 52795293, 2006, http://www.atmos-chem-phys.net/6/5279/2006/.

Berndt, T., Böge, O., and Stratmann, F.: Gas-phase ozonolysis of $\alpha$-pinene: gaseous products and particle formation, Atmos. Environ. 37, 3933-3945, 2003.

Brechtel F. J. and Kreidenweis S. M.: Predicting particle critical supersaturation from hygroscopic growth measurements in the humidified TDMA. part I: Theory and sensitivity studies, J. Atmos. Sci., 57, 1854-1871, 2000.

Carter, W. P. L., Cocker, D. R., Fitz, D. R., Malkina, I. L., Bumiller, K., Sauer, C. G., Pisano, J. T., Bufalino, C., and Song, C.: A new environmental chamber for evaluation of gas-phase chemical mechanisms and secondary aerosol formation, Atmos. Environ., 39, 7768-7788, 2005.

Cocker, D. R., Clegg, S. L., Flagan, R. C., and Seinfeld, J. H.: The effect of water on gas-particle partitioning of secondary organic aerosol. Part I: $\alpha$-pinene/ozone system, Atmos. Environ. 35, 6049-6072, 2001a.

Cocker, D. R., Flagan, R. C., and Seinfeld, J. H.: State-of-the-art facility for studying atmospheric aerosol chemistry, Environ. Sci. Technol., 35, 2594-2601, 2001b.

Cocker, D. R., Mader, B. T., Kalberer, M., Flagan, R. C., and Seinfeld, J. H.: The effect of water on gas-particle partitioning of secondary organic aerosol: II. m-xylene and 1,3,5trimethylbenzene photooxidation systems, Atmos. Environ., 35, 6073-6085, 2001c.

Davidson, C. I., Phalen, R. F., and Solomon, P. A.: Airborne Particulate Matter and Human Health: A Review, Aerosol Sci. Technol., 39, 737-749, 2005.

DeCarlo, P. F., Kimmel, J. R., Trimborn, A., Northway, M. J., Jayne, J. T., Aiken, A. C., Gonin, M., Fuhrer, K., Horvath, T., Docherty, K., Worsnop, D. R., and Jimenez, J. L.: Field-Deployable, HighResolution, Time-of-Flight Aerosol Mass Spectrometer, Anal. Chem., 78, 8281-8289, 2006.

Ehara, K., Hagwood, C., and Coakley, K. J.: Novel method to classify aerosol particles according to their mass-to-charge ratioaerosol particle mass analyzer, J. Aerosol Sci., 27(2), 217-234, 1996.

Eldering, A. and Cass, G. R.: Source-oriented model for air pollutant effects on visibility, J. Geophys. Res.-Atmos., 101, 1934319369, 1996.

Griffin, R. J., Cocker, D. R., Flagan, R. C., and Seinfeld, J. H.: Organic aerosol formation from the oxidation of biogenic hydrocarbons, J. Geophys. Res.-Atmos., 104, 3555-3567, 1999.

Hildebrandt, L., Donahue, N. M., and Pandis, S. N.: High formation of secondary organic aerosol from the photo-oxidation of toluene, Atmos. Chem. Phys., 9, 2973-2986, 2009,

http://www.atmos-chem-phys.net/9/2973/2009/.

Hoffmann, T., Odum, J. R., Bowman, F., Collins, D., Klockow, D., Flagan, R. C., and Seinfeld, J. H.: Formation of organic aerosols from the oxidation of biogenic hydrocarbons, J. Atmos. Chem., 26, 189-222, 1997.

Intergovernmental Panel on Climate Change (IPCC) Fourth Assessment Report: Climate Change 2007.

Jimenez, J. L., Jayne, J. T., Shi, Q., Kolb, C. E., Worsnop, D. R., Yourshaw, I., Seinfeld, J. H., Flagan, R. C., Zhang, X., Smith, K. A., Morris, J., and Davidovits, P.: Ambient Aerosol Sampling with an Aerosol Mass Spectrometer, J. Geophys. Res.-Atmos., 108(D7), 8425, doi:10.1029/2001JD001213, 2003.

Kalberer, M., Paulsen, D., Sax, M., Steinbacher, M., Dommen, J., Prévôt, A. S. H., Fisseha, R., Weingartner, E., Frankevich, V., Zenobi, R., and Baltensperger, U.: Identification of Polymers as Major Components of Atmospheric Organic Aerosols, Science, 303, 1659-1662, 2004.

Malloy, Q. G. J., Nakao, S., Qi, L., Austin, R., Stothers, C., Hagino, H., and Cocker, D. R.: Real-Time Aerosol Density Determination Utilizing a Modified Scanning Mobility Particle SizerAerosol Particle Mass Analyzer System, Aerosol Sci. Technol., 43, 673-678, 2009.

Odum, J. R., Hoffmann, T., Bowman, F., Collins, D., Flagan, R. C., and Seinfeld, J. H.: Gas/particle partitioning and secondary 
organic aerosol yields, Environ. Sci. Technol., 30, 2580-2585, 1996.

Pankow, J. F.: An absorption-model of gas-particle partitioning of organic compounds in the atmosphere, Atmos. Environ., 28, 185-188, 1994a.

Pankow, J. F.: An absorption-model of the gas aerosol partitioning involved in the formation of secondary organic aerosol, Atmos. Environ. 28, 189-193, 1994b.

Pathak, R. K., Presto, A. A., Lane, T. E., Stanier, C. O., Donahue, N. M., and Pandis, S. N.: Ozonolysis of $\alpha$-pinene: parameterization of secondary organic aerosol mass fraction, Atmos. Chem. Phys., 7, 3811-3821, 2007, http://www.atmos-chem-phys.net/7/3811/2007/.

Pathak, R. K., Stanier, C. O., Donahue, N. M., and Pandis, S. N.: Ozonolysis of $\alpha$-pinene at atmospherically relevant concentrations: temperature dependence of aerosol mass fractions (yields), J. Geophys. Res.-Atmos., 112, D03201, doi:10.1029/2006JD007436, 2007.

Philippin, S., Wiedensohler, A., and Stratmann, F.: Measurements of non-volatile fractions of pollution aerosols with an eight-tube volatility tandem differential mobility analyzer (VTDMA-8), J. Aerosol Sci., 35, 185-203, 2004.

Pope, C. A. and Dockery, D. W.: Health effects of fine particulate air pollution: lines that connect, J. Air Waste Manage. Assoc., 56, 709-742, 2006.

Qi, L., Nakao, S., Malloy, Q., Warren, B., and Cocker, D. R.: Can secondary organic aerosol formed in an atmospheric simulation chamber continuously age?, Atmos. Environ., under review, 2009.

Shilling, J. E., Chen, Q., King, S. M., Rosenoern, T., Kroll, J. H., Worsnop, D. R., McKinney, K. A., and Martin, S. T.: Particle mass yield in secondary organic aerosol formed by the dark ozonolysis of $\alpha$-pinene, Atmos. Chem. Phys., 8, 2073-2088, 2008 ,

http://www.atmos-chem-phys.net/8/2073/2008/.
Stanier, C. O., Pathak, R. K., and Pandis, S. N.: Measurements of the volatility of aerosols from alpha-pinene ozonolysis, Environ. Sci. Technol., 41, 2756-2763, 2007.

Takekawa, H., Minoura, H., and Yamazaki, S.: Temperature dependence of secondary organic aerosol formation by photo-oxidation of hydrocarbons, Atmos. Environ., 37, 3413-3424, 2003.

Turpin, B. J. and Huntzicker, J. J.: Identification of secondary organic aerosol episodes and quantitation of primary and secondary organic aerosol concentrations during SCAQS, Atmos. Environ., 23, 3527-3544, 1995.

Warren, B., Austin, R. L., and Cocker, D. R.: Temperature dependence of secondary organic aerosol, Atmos. Environ., 43, 35483555, 2009a.

Warren, B., Song, C., and Cocker, D. R.: Light intensity and light source influence on secondary organic aerosol formation for the m-xylene/NOx photooxidation system, Environ. Sci. Technol., 42, 5461-5466, 2009b.

Zhang, Q., Jimenez, J. L., Canagaratna, M. R., Allan, J. D., Coe, H., Ulbrich, I., Alfarra, M. R., Takami, A., Middlebrook, A.M., Sun, Y. L., Dzepina, K., Dunlea, E., Docherty, K., DeCarlo, P. F., Salcedo, D., Onasch, T., Jayne, J. T., Miyoshi, T., Shimono, A., Hatakeyama, S., Takegawa, N., Kondo, Y., Schneider, J., Drewnick, F., Borrmann, S., Weimer, S., Demerjian, K., Williams, P., Bower, K., Bahreini, R., Cottrell, L., Griffin, R. J., Rautianinen, J., Sun, J. Y., Zhang, Y. M., and Worsnop, D. R.: Ubiquity and dominance of oxygenated species in organic aerosols in anthropogenically-influenced Northern Hemisphere midlatitudes, Geophys. Res. Lett., 34, L13801, doi:10.1029/2007GL029979, 2007. 